\title{
CONTRIBUTIONS FROM THE ROCKY MOUNTAIN HERBARIUM. II.
}

\author{
AVEN NELSON.
}

SOME COLORADO SPECIES.

As interesting collection of Colorado plants, some 300 numbers, was kindly submitted to me for examination by Professor Ramaley, of the University of Colorado. They were largely of his own collecting, but some of them were by F. Y. Moseley, and yet others by Jennie M. Archibald, of Berwind, Colorado. Among them were many of much interest and a few novelties, upon which the following notes and characterizations are offered.

Zygadenus Coloradoensis Rydb. This interesting recently described ally of $Z$. elegans seems to be peculiarly a Colorado species, as I have not yet met with it in Wyoming.

Cheiranthus sp. A peculiarly branched form, with petals almost rose-colored, was represented by two numbers. It was evidently not far from $C$. asper Nutt., but fruiting specimens may show it to be distinct.

Clematis Scottin Porter. This rare plant was represented by rather young specimens, but even these indicated the distinctness of the species as compared with $C$. hirsutissima Pursh.

Saxifraga Rhomboidea austrina, n. var.-Size, habitat and foliage of the species: stems not rarely several from the short rootstock, pubescent with gland-tipped hairs as is also the inflorescence: inflorescence paniculately cymose, strict: calyx lobes obtuse, as long as the adnate base: petals elliptic, white, $3^{\mathrm{mm}}$ long: carpels ovoid, the tips at length widely divaricate: seeds very numerous, brown, oblong, more or less subacute at both ends.

That this is a good species seems quite possible. The paniculate inflorescence and conspicuously gland-tipped pubescence is in strong contast to the usually spherical terminal cluster (which at most becomes only branchedthyrsiform) and the glandless pubescence of $S$. rhomboidea Greene, Pitt. 
$3: 343$. In the variety proposed the petals are not emarginate, the calyx lobes are longer than in the species; the presence of a rather conspicuous ciliate-pubescence on the margins of the leaf in the variety adds another point of contrast.

Excellent specimens are in hand from Jennie M. Archibald, Berwind, Colorado, I900, no. 236.

Parosela Porteri, n. sp. - Caudex woody, with a deepset woody root: stems numerous from the enlarged crown, prostrate-assurgent, quite unequal in length, IO-2 $5^{\mathrm{cm}}$ long (including the oblong spike), strigose, appressed-pubescent: leaves trifoliate, densely appressed strigose-silky, cuneately obovate or narrower, mostly obtuse, $8-14^{\mathrm{mm}}$ long, the terminal one longer than the lateral pair, barely petiolulate, generally shorter than the slender petiole; stipules slenderly and stiffly setaceous, $5-6^{\mathrm{mm}}$ long: spike dense, $2-5^{\mathrm{cm}}$ long; bracts purple, lanceolate-acuminate, equaling or shorter than the calyx, silkyvillous; calyx tube campanulate, membranous with ten greenish nerves, the triangular base of its lobes abruptly narrowed into long slender plumose setae which are twice as long as the tube; corolla lemon-yellow; the standard very short, reniform-triangular, acute, broader than long, shorter than the slender claw; the wings oval, short clawed; keel petals oval or even broader, surpassing the wings, the blade about $6^{\mathrm{mm}}$ long and the claw about $2^{\mathrm{mm}}$; ovary silky, included in the calyx tube, half as long as the slender plumose style which is much exceeded by the calyx lobes.

The somewhat varying descriptions of Parosela Jamesii indicate that more than one species has been distributed under this name. That the species now proposed is the Dalea Jamesii of Porter, Fl. Colorado, seems probable, but from the original as described in T. \& G. Fl. N. Am. 308, the following points seem to separate it. P. Porteri is more prostrate spreading, the leaves are narrower and are shorter than the petioles, the pubescence is coarser, it has purple bracts, the flowers are yellow not purple, and the wings and keel are oval not oblong as in $P$. Jamesii. ${ }^{\text {. }}$

Collected at Berwind, Colorado, I 9oo, by Jennie M. Archibald, no. 244.

Petalostemon pubescens, n. sp.-Roots woody; the crown thick, simple or branched: stems numerous, the exterior ones

${ }^{x}$ Dr. Gray in redrawing the description for Pl. Wright. 49 , seems to have so modified the original description as possibly to include $P$. Porteri. 
prostrate-assurgent, the central suberect, $\mathrm{I}-2^{\mathrm{dm}}$ long, whitish with a sublanate pubescence: leaves neither glandular nor dotted, 5foliate, nearly glabrous above, the pubescence underneath and on the petioles resembling that on the stems; leaflets spatulatelinear, sessile, $\mathrm{IO}-\mathrm{I} 4^{\mathrm{mm}}$ long; petioles about as long, often with a pair of diminutive trifoliate leaves in the axils; stipules filiform : spike oblong, dense, $2-5^{\mathrm{cm}}$ long, $\mathrm{I}^{\mathrm{cm}}$ or less in diameter; peduncles short $\left(\mathrm{I}-5^{\mathrm{cm}}\right)$ : bracts scarcely equaling the calyx, obovate, abruptly acuminate, the dark purple tip obscured by the copious silvery lanate pubescence of the spike as a whole: calyx $4-5^{\mathrm{mm}}$ long, the teeth shorter than the tube: petals light purple; the limb of the standard broadly cordate, about $3^{\mathrm{mm}}$ in diameter, exceeded by the filiform claw: ovary and base of style softly pubescent.

Most nearly allied to $P$. tenuifolius Gray, from which it is at once to be distinguished by its very different habit, shorter broader leaflets, shorter peduncles and slenderer spikes, obovate short-acuminate purple tipped bracts, light purple petals, and the almost entire absence of glands or dots anywhere on the plant.

The species is founded on no. 247 from Berwind, Colorado, by Jennie M. Archibald.

Gentiana Moseleyi, n. sp.- Perennial from slender fleshy rootstocks, about $\mathrm{I}^{\mathrm{dm}}$ high, glabrous throughout, I-2-flowered (possibly more): leaves about 4 pairs, two of which are basal and nearly verticillate, from narrowly oblanceolate and petioled below to broadly linear and sessile above, $2-3^{\mathrm{cm}}$ long: the terminal flower subtended by a pair of foliar linear-lanceolate bracts often nearly as long as the calyx; additional flowers (if any) axillary in the uppermost leaves and smaller: calyx green with purple streaks, about $\mathrm{I}_{5}^{\mathrm{mm}}$ long; the lobes triangular-lanceolate, equaling or exceeding the tube: corolla dark blue, about $25^{\mathrm{mm}}$ long; the lobes oblong, obtuse, exceeding the tube ( $5^{\mathrm{mm}}$ long), $5-7^{\mathrm{mm}}$ broad, conspicuously long setaceous-lacerate on the sides and often nearly to the summit which is obscurely dentate; the tube arachnoid woolly within especially toward the base: filaments stout, flattened, equaling the tube: stipe half as long as the elliptic-oblong capsule: style almost wanting. 
The habit and general appearance of this excellent species is much like G. elegans unicaulis Aven Nelson. In fact at first glance I thought of it as that, but no one really stopping to look at it can possibly mistake one for the other. G. Moseleyi is certainly a perennial ; the conspicuous fringe upon the corolla lobes which exceed the tube and the sessile stigmas at once mark it as distinct from the other.

The specimens were collected by, F. Y. Moseley in Boulder county, Colorado, 1896 . The exact locality is not known, but it probably was in some of the higher mountains.

Polemonium Archibaldae, n. sp.-Stems tall $\left(4-7^{\text {dm }}\right)$, erect, slender, sparsely pubescent but not glandular except in the inflorescence: leaves glabrate, deeply pinnately divided, the midrib merely narrowly margined between the segments and on the very short petiole, 8-I $2^{\mathrm{cm}}$ long; the segments subpaired, I3-I9, oblong-lanceolate: inflorescence corymbose-cymose, minutely glandular-pubescent especially on the calyx; the small cymes (5-9-flowered) erect, congested (the pedicels very short); peduncles slender, the lower 5-10 ${ }^{\mathrm{cm}}$ long: calyx campanulate, $6-7^{\mathrm{mm}}$ long, the lanceolate lobes as long as the tube: corolla rotate-campanulate, IO- $4^{\mathrm{mm}}$ in diameter, the lobes suborbicular, as long as the tube, from deep purple to much lighter: filaments filiform, a little shorter than the corolla, glabrous except at the insertion where they are densely and finely pubescent; anthers oblong, large, $3^{\mathrm{mm}}$ long: stigmas scarcely exserted.

This species is closely related to $P$. filicinum Greene, but differs from that in the somewhat narrower leaves, in the ampler inflorescence, in orbicular (not acute) corolla lobes, in the relatively shorter calyx lobes, in its erect (not declined) stamens, and in its shorter style. The inflorescence is probably also much less glandular, for Dr. Greene characterizes $P$. filicinum as being densely glandular-viscid in the inflorescence.

The species is dedicated to Jennie M. Archibald, who secured at Berwind, Colorada, in I900, a most interesting collection. The type is in the Rocky Mountain Herbarium, no. 220 of the collection mentioned.

Monarda Nuttallii, n. n.-Monarda aristata Nutt., Trans. Am. Phil. Soc. n. ser. 5: I86. I837; not Monarda aristata Hook., Bot. Mag. t. 3526. I836. This has been for some time included in Monarda citriodora Cerv., but any suite of specimens of the two shows that they are distinct. $M$. citriodora is a larger, coarser 
plant, with broader leaves; the bracts more deeply colored, longer, more abruptly aristate and less strongly ciliate than in $M$. Nuttallii. The latter has the mid-nerve of the bracts relatively much more conspicuous than the others, and the aristate calyx lobes strikingly ciliate-bearded.

$M$. Nuttallii is well represented by the following specimens, all from Colorado: 166, Professor Francis Ramaley, Boulder, I 900; C. S.Crandall, Fort Collins, I893; Marie Holzinger, Boulder, I892; 614, Baker, Earle, and Tracy, Durango, $1898 ; 428$ of the Hall and Harbour plants.

In this connection I would inquire why Monarda aristata Hook. should not be restored as a substitute for $M$. clinopodioides Gray?

Monarda Ramaleyi, n. n.- Rootstocks horizontal, rather slender, abundantly and conspicuously rootbearing: stems erect, or sometimes decumbent and somewhat flexuous, mostly simple and monocephalous, $3-6^{\mathrm{dm}}$ high, glabrate below, softly lanately white-pubescent upward, densely so at the nodes, more or less purplish: leaves lanceolate or ovate lanceolate, broadly rounded or subtruncate at base, sharply but rather remotely serrate, softly pubescent especially below; petioles very short, less than $\mathrm{I}^{\mathrm{cm}}$, the uppermost almost wanting, lanately pubescent as are also the midribs of the leaves: involucral leaves about 6 or, counting the approximated uppermost stem pair, 8 , ovate, acute, entire, $2-3^{\mathrm{cm}}$ long, obscurely tinged with purple: floral bracts slenderly linearsubulate, ciliate-hispid on the margins, about $\mathrm{I}^{\mathrm{cm}}$ long: calyx tubular, minutely puberulent, $8-10^{\mathrm{mm}}$ long, the five equal subulate teeth very short and somewhat hispid-pubescent at base: corolla lilac-purple, softly pubescent, strongly bilabiate; the tube within the calyx very narrowly linear, dilating gradually above, the exserted portion exceeding the calyx; upper lip linear-lanceolate, but slightly curved, IO-I $2^{\mathrm{mm}}$ long; lower lip oblong-elliptic, as long at the upper, obtuse and broadly emarginate at apex, with a short, broadly linear, cucullate, pubescent appendage from the notch; the appendage bidentate: stamens 2 , exserted, exceeded by the pistil.

This species at once presents a very different appearance from the only two species with which it can be compared, viz., $M$. menthaefolia Graham and $M$. stricta Wooton. On suggesting to Professor Ramaley that it was probably 
new, he very kindly supplied me with a good series of specimens from which the characters are drawn. It may at once be distinguished by its rather low, strict, usually monocephalous stems, its unusual pubescence, its almost lavender corollas, and the peculiar appendage-like appearance of the middle lobe of the lower lip.

I am informed that it occurs rather sparingly in sandy soil near Boulder creek, Boulder, Colorado, where it was collected by Professor Ramaley (to whom it is dedicated) June 27 , I900, no. 92.

Phacelia heterophylla Pursh. The Rocky mountain speci mens of this species seem somewhat aberrant, but the characters so far as made out do not seem to warrant separation.

Mimulus Langsdorfil Tilingi (Regel) Greene? A peculiarly pubescent form was sparingly represented. It seems probable that fuller material may show this to be distinct.

Lithospermum Linearifolium Goldie was represented by several numbers and showed much diversity. However, since these numbers represented different localities and plants in different stages of maturity no dependence can be placed on the diversity shown. In this species and its allies successive collections shouid be made during the season from what is undoubtedly the same community of plants.

Chrysopsis Fulcrata Greene. What seems to be a pretty good match for the type number of this species, originally described from New Mexican material, was collected near Boulder.

Oonopsis monocephala, n. sp-Caudex woody, its branches slender: stems one or more from each branch of the caudex, erect or ascending, $\mathrm{I}-2^{\mathrm{dm}}$ high, simple, uniformly leafy from base to summit, monocephalous: leaves glabrous as are also the stems, linear-oblong, sessile, acute, quite uniform in size and shape, $5-8^{\mathrm{cm}}$ long, about $\mathrm{I}^{\mathrm{cm}}$ broad, the uppermost involucrating the large head: involucre hemispherical, about $15^{\mathrm{mm}}$ high; the bracts oblong, rather abruptly short acuminate-cuspidate, glabrous but for some ciliate pubescence on the margins: heads rayless; disk flowers very numerous: pappus nearly as long as the corolla tube, the bristles widely spreading at maturity: akene oblong, about $3^{\mathrm{mm}}$ long, sparsely and obscurely glandular. 
I am aware in pronouncing this plant an Oonopsis that I am putting into this genus a monocephalous species and another rayless one, but the habit is thoroughly characteristic. The hue of the leaves, which retain their foliar character up to the heads which they surpass, the appearance of the involucre, and the floral characters are in perfect accord with the genus.

The specimens upon which the species is founded were submitted to me by Professor Ramaley, of the University of Colorado, and are the collection of Jennie M. Archibald, at Berwind, Colorado, in I900, no. 257.

WESTERN EUPATORIEAE.

Eupatorium atromontanum, n. Sp.-Tall, I-2 ${ }^{\mathrm{m}}$ high: stems with an obscure short white puberulence, striate, greenish or mottled with purplish-brown: leaves verticillate in fours, short petioled, ample, from ovate-acute to lanceolate-acuminate on the same plant, I $2-25^{\mathrm{cm}}$ long, $4-\mathrm{IO}^{\mathrm{cm}}$ broad, much exceeding the internodes, coarsely serrate, the teeth broadly triangular and apiculate, rather thin, prominently veined below, glabrate above and dark green, lighter and with a short fuscous puberulence underneath, sprinkled with minute, shining, resinous dots: inflorescence corymbose-cymose or more paniculate, equaled or more often overtopped by the uppermost leaves; the peduncles of the cymes arising from the axils of the leaves of the 2 or 3 uppermost verticils cinerous-pubescent as are also the numerous short slender pedicels: involucral bracts in 4 or 5 series; the outer short, elliptic ; the second and third more broadly elliptic or oval, about $7^{\mathrm{mm}}$ long, pubescent, with 3 greenish striae and scarious margins; the inner and longest becoming oblong and almost wholly scarious: heads about I5-flowered: corollas tubular (hardly at all dilated upwards) : akene obscurely angled, dotted with resin particles, linear, but slightly shorter than the somewhat unequal pappus.

This finds its nearest ally in the somewhat polymorphous E. maculatum L. The more typical form of that differs from this in the thicker, usually rugose leaves which at the summit become smaller or bract-like, leaving the inflorescence naked (surpassing the leaves). That also has a harsher, more copious pubescence, different involucral bracts, and fewer flowers in the head.

E. atromontanum is represented in the Rocky Mountain Herbarium by two collections, as follows; 225 I, Sheridan, July 10, 1896; 2553, Beaver creek, Black hills, Wyoming, July 30, 1896 (type). 
Coieosanthus congestus, n. sp.- Roots fascicled, large, semifleshy, with a woody crown: stems several to numerous, ascending or nearly erect, simple, $3^{-6^{\mathrm{dm}}}$ long, minutely pubescent, obscurely striate: leaves opposite below, only the uppermost alternate, green and nearly glabrous, or obscurely roughenedscabrous, especially on the veins below, lightly sprinkled with resin particles, deltoid-triangular, with truncate or cordate base, from sub-acute to acuminate, $3-6^{\mathrm{cm}}$ long, crenately-serrate, the apex entire; petioles variable, very short to equaling or surpassing the blade: inflorescence congested at the summit of the simple stems, the crowded cymes of the few heads subtended by foliar bracts, sometimes one or more additional cymes terminal on widely divaricate or ascending peduncles from the axils of the uppermost leaves: heads IO-I $2^{\mathrm{mm}}$ high, subtended by a few loose long-acuminate bracts; the involucral bracts in about 5 series, the outermost ovate, acuminate, pubescent and ciliate on the margins; the succeeding rows passing from broadly lanceolate to broadly linear, green between the 3 or 4 raised white striae and ciliate on the scarious margin: flowers about 50: corolla narrow, tubular, about $7^{\mathrm{mm}}$ long: anthers wholly included within the tube proper: style branches spatulate-clavate, the exserted portion about $3^{\mathrm{mm}}$ long: akenes linear-cylindric, subglabrous, IO-striate, $3-4^{\mathrm{mm}}$ long.

This is undoubtedly, in part, the Brickellia grandiflora of Gray, Syn. Fl. 105, but is certainly distinct from Eupatorium(?) grandifforum Hook. Fl. $2: 26$, and probably from Brickellia grandiflora Nutt. Trans. Am. Phil. Soc. n. ser. $7: 287$. The original seems to have been a tall, probably singlestemmed plant, paniculately branched at the summit, with larger, fewerflowered heads, and white corollas. This Oregon plant is probably in large part the Coleosanthus grandiflorus of the recent Flora of N. W. America 203, by Howell, who writes from near the type locality. The tufted habit, simple stems, congested inflorescence, and more numerous flowers of $C$. congestus seem to me to be specific characters.

The collections at hand are: 423 , Fairbanks, July 10, I894; 1687, Cummins, July 16, 1895; 4212, Battle lake, August 17, 1897; 7506, Antelope basin, July 8, I goo (type); also Palmer lake, Colorado, August 12, 1896, by Professor C. S. Crandall. 
Kuhnia Fitzpatricki, n. sp.-Stems I-several, with a woody root, erect, $\mathrm{I}^{\mathrm{m}}$ (more or less) high: stems simple, rather slender, light green, obscurely striate, scarcely puberulent: leaves numerous, very uniformly distributed except near the base where they are early deciduous, green and appearing glabrous but puberulent or minutely scabrous especially on the margins or veins, thin, not impressed punctate and the resin particles microscopic, very uniform in shape and size, narrowly lanceolate, the cuneate base subpetiolate and with I or more linear bracts in the axils, 8-I $2^{\mathrm{cm}}$ long, $8-\mathrm{I} 5^{\mathrm{mm}}$ wide, coarsely and somewhat uniformly toothed, upwardly becoming narrower, entire and in the short inflorescence somewhat reduced: cymes few and of few heads, crowded: pedicels and involucre softly pubescent; the outer bracts filiform; the inner broadly linear, acuminate: corolla purple(?), tube short, very slender, dilated at base, expanding into a much longer cylindrical throat: akene fusiform, $5^{\mathrm{m}}$ long, equaled by the very fine white pappus.

This remarkably distinct species from the prairies of Iowa, I have from T. J. and M. F. L. Fitzpatrick, who collected it in Decatur county, September 25,1899 , where it is said to be common. It was distributed as $K$. eupa. torioides L: (var. ?).

Kuhnia Gooddingi, n. sp.- Perennial, from a densely caespitose-tufted caudex: stems very numerous, loosely spreading, $5^{-8^{d m}}$ high, simple and almost leafless below, striate and minutely puberulent: leaves numerous, crowded on the middle portion of the stem, sparsely and minutely puberulent especially on the margins and veins, linear to narrowly lanceolate, $2-4^{\mathrm{cm}}$ long, entire or nearly so, more or less revolute-margined, minutely impressed-punctate on both surfaces, those of the inflorescence gradually reduced and linear-bracteate: inflorescence loosely and widely paniculate, occupying the upper third of the plant: the pedicels and involucre finely pubescent : involucres turbinate, the bracts in about five series; the outer short, lanceolate; the inner broadly linear, with villous-pubescent setaceous tip, about 4-striate, sparsely sprinkled with shining resinous particles as are also the corolla teeth: disk $10-12^{\mathrm{mm}}$ high, $15-25$-flowered; 
corolla ochroleucous or shading to brown, slender, tubular; akene linear, finely about 20-striate, only a little shorter than the white finely plumose pappus.

No western species of Kuhnia have heretofore been described. They occur but rarely, but at least two good species seem to belong to the eastern Rocky mountains. This species now proposed is one of the strongest of these, and differs so radically in habit, to say nothing of the other characters, that it seems unnecessary to call attention to the points of divergence from the well known species.

It was secured by Mr. Leslie Goodding, to whom it is dedicated, in a mountain valley, West Dry creek, Larimer county, Colorado, where it occurred in the greatest abundance, usually in stony places, but with the tufted stems and woody caudex imbedded in low mounds of loose drifting soil. The type number is 8202 .

Kuhnia Hitchcocki, n. sp.- Tufted-suffrutescent, the lignescent stems decumbent-spreading, each divaricately branched from the base up, dark in hue but minutely puberulent as are also the leaves: stem leaves mostly wanting (or if but little branched, very numerous), nearly linear, with a few sharp teeth, $3-4^{\mathrm{cm}}$ long; those of the rigid branches numerous, small, linear, $2-3^{\mathrm{cm}}$ long, passing into the bractlets: involucre usually subtended by a few linear bractlets, its bracts in about 5 series, the short outer ones broadly lanceolate, the inner broadly linear with thin scarious margins and cuspidate apex: disk corollas 20-30, the tube nearly uniform: akenes small, about Io-striate, shorter than the dull-white to tawny distinctly plumose pappus.

This species seems to belong to the arid plains east of the Rocky mountains. It has been frequently collected by Professor A. S. Hitchcock (to whom I am pleased to dedicate the species) in several of the counties of Kansas. Among the large series of specimens that his courtesy has enabled me to examine, the following may be named as typical: 2 I $1 a$, Meade county, September 1897; Edwards county, September 1897; Stafford county, September 1897; Clark county, August 1896; Kiowa county, August 1896; Barton county, August 1895 .

Kuhnia reticulata, n. sp.-Caudex woody: stems several or many, ascending, $3-4^{\mathrm{dm}}$ high, simple, light green, finely puberulent: leaves light green, appearing glabrous but puberulent on 
the upper face and on the veins and margins, closely impressedpunctate on both faces, the veins on the lower surface raisedreticulate, oblong-lanceolate, $2-4^{\mathrm{cm}}$ long, subacute, from entire to irregularly few toothed, usually some small fascicled linear leaves in the axils, smaller upward and passing into the bracts of the short inflorescence: cymes of few heads, congestedcorymbose or becoming paniculate: involucre turbinate-campanulate; the bracts in 4 or 5 series, softly pubescent, strongly nervose, resin-sprinkled, shorter than the $\mathrm{I} 2-\mathrm{I} 5^{\mathrm{mm}}$ high disk; the outer short, lanceolate; the inner broadly linear, acute: flowers about 25: the corollas linear-cylindric, but slightly dilated at base, about $8^{\mathrm{mm}}$ long: style tips compressed, linear, not dilated-clavate at summit: akenes 20 -striate, some of the striae more prominent than the others, linear, about $5^{\mathrm{mm}}$ long, exceeded by the white softly plumose pappus.

This species is perhaps most nearly allied to $K$. glutinosa Ell., but the points of distinction are so patent that to call attention to them seems unnecessary.

The only collection of it is no. 2771, Platte cañon, Laramie county, Wyoming, August 27, 1896. Some specimens of it were distributed as $K$. eupatorioides corymbosa T. \& G.

Lacinaria alata, n. sp.-Tall, $8^{\mathrm{dm}}$ to probably twice as high: stem stout, striate, puberulent: leaves numerous and crowded (especially on the middle portion of the stem), quite similar throughout (root leaves not seen), glabrous, closely and uniformly punctate, linear-oblong, acute; the lower 8-1 $2^{\mathrm{cm}}$ long, mostly less than $\mathrm{I}^{\mathrm{cm}}$ broad, deflexed on the short margined petioles, upwardly becoming smaller sessile and erect, passing into the large foliar bracts of the spike: spike $3-5^{\mathrm{dm}}$ long, crowded: heads sessile or nearly so, numerous (30-50), about I $5^{\mathrm{mm}}$ high, equally broad, $35-45$-flowered: the involucral bracts in about 6 series, minutely punctate, purplish; the outer very short, ovate, acute, green, rarely slightly scarious-winged near the summit; the succeeding 2 or 3 series similar as to the foliaceous center but conspicuously and broadly scarious-winged toward summit, becoming broadly obcordate in outline, the wings from entire to dentate or even lacerate, about $\mathrm{I}^{\mathrm{cm}}$ long 
and broad; the inner series longer and narrower, scarious margined all around: corolla resin-dotted throughout, 8-10 $\mathrm{mm}^{\mathrm{m}}$ long, the broadly linear lobes half as long as the tube which is stiffly pubescent within near the base: style branches as long as the corolla; akene narrowly obovate, dark brown with short whitish spreading pubescence, about $5^{\mathrm{mm}}$ long: receptacle nearly plane, with shallow alveolations.

The plants upon which this species is founded were collected by $J$. $H$. Kimmons, August 1895 , in the Creek Nation, I. T., and distributed by Professor J. W. Blankinship as Liatris scariosa Willd. From this there are many characters to separate it, but attention need only be called to the reflexed lower leaves, the long foliar-bracted spike, and the alate bracts of involucre.

Lacinaria ligulistylis, n. sp.-Perennial, from an enlarged woody tuberous root: stems single, light green, glabrate below, lightly white pubescent above, striate, $4-5^{\mathrm{dm}}$ high, uniformly leafy from the base up: leaves bright green, rather obscurely punctate, glabrous, usually minutely ciliate on the slightly thickened margin; the lower lance-oblong, 8-I $2^{\mathrm{cm}}$ long, tapering into a usually much shorter margined petiole; upwardly becoming more lanceolate, the winged base shorter, gradually smaller, passing into the lance-linear bracts of the inflorescence: heads from few to several, racemose: peduncles $\mathrm{I}-3^{\mathrm{cm}}$ long, tinged with purple as are also the peduncle and rachis: involucre broadly campanulate, often $20-25^{\mathrm{mm}}$ broad; bracts in about 6 series, foliar-green with dark purple scarious dentate margins; the outer short, from nearly orbicular to oval; the middle rows broadly obovate; the inner elliptic or oblong and $\mathrm{I} 5-\mathrm{I} 8^{\mathrm{mm}}$ long: flowers 50-70, purple: corolla tube slightly dilated upward; the teeth lanceolate, one third as long as the tube, with a delicate marginal vein: exserted style branches flattened, as long as the corolla, light purple, conspicuous and superficially suggesting the slender rays of some Erigeron; akene flattened, finely pubescent, nearly as long as the corolla tube.

The Rocky mountain forms of Lacinaria that have passed as L. scariosa (L.) Hill are clearly distinct from the eastern forms. That, even with the Rocky mountain form eliminated, L. scariosa, as applied to the eastern forms, 
is still an aggregate seems to me more than probable. In spite of the extended synonomy of this species, the various names all seem to be associated with the forms of the eastern or the Mississippi valley states. Some of the descriptions of L. scariosa, however, probably cover or may even be founded upon the western or Rocky mountain form, notably that of Hooker, Fl. r: 306 .

The species now proposed is at once distinct from the Serratula scariosa L. and the Liatris scariosa Willd., and surely from the spicate forms of the Mississippi valley. The smooth leaves gradually diminishing upwards, the relatively short margined petioles also diminishing upward, the clearly racemiform purple inflorescence, the large heads, the appressed involucre, the very conspicuous style-branches, and the numerous flowers will serve to distinguish $L$. ligulistylis.

The following collections are cited as typical: I65I, Laramie peak, August 8, I895 (type); 69I, by C. F. Baker, Pagosa springs, Colorado, August 30,$1899 ; 4554$, by F. H. Snow, Colorado; G. E. Osterhout, Steamboat springs, Colorado, August 24, I899; less typical my numbers from Inyan Cara divide, August 20, I892; and Buffalo, July 26, I 896.

\section{STUDIES IN ARNICAS.}

The collector and the student of the Rocky mountain Arnicas has in the past found many difficulties with which to contend. So many of the species attributed to this region were originally described from such widely different geographical ranges that it ought to have been expected that no close agreement would be found between our species and those of the earlier investigated localities. The recent activity in taxonomic botany is bringing to light many real novelties and separating many of the heretofore uncertain but well-known forms. It is perhaps inevitable that at such a time some confusion should result, but perhaps the sooner synonyms and homonyms are cleared up the better. The following have come under my obser vation :

Arnica multiflora Greene, Pitt. 4:162, evidently is $A$. Columbiana Aven Nelson, Вот. GAz. 30:200, since both are, in part, founded on the same collections and the same numbers are cited. The latter name is the earlier by two or three months. Dr. Greene's A. Columbiana (Pitt. 4: I59) having thus become a homonym it may become Arnica Greenei, n. n. 
Arnica platyphylla, n. sp.- Perennial from woody rhizomes, $3^{-6^{\mathrm{dm}}}$ high, rather slender, the internodes subequal, nearly glabrous throughout, the leaves very thin and delicate in texture: the leaves that spring in fascicles of $3-5$ from the rhizome oval to oval-subcordate, sinuately dentate as are also the stem leaves, obtuse or acute, ciliolate on the margins, $4-6^{\mathrm{cm}}$ long, equaled by the slender petioles: stem leaves 2-4 pairs and a pair of sheathing scales at base, all closely sessile by broadly rounded or truncate base; if only 2 pairs, similar in size and shape; if 4 pairs, the upper and the lower smaller than the two middle pairs; from nearly orbicular to broadly ovate and subacute, $5-10^{\mathrm{cm}}$ long: heads $3-5$; if three, on slender nearly equal peduncles, subtended by ovate-acuminate bracts $2-3^{\mathrm{cm}}$ long; if five, the lowest pair from the uppermost leaves and borne on elongated slender petioles: involucres somewhat turbinate, slightly glandular-pubescent as are also the peduncles; scales thin, narrowly obovate-acuminate, in one series: rays few, long, bright yellow: tube of disk corollas pubescent, very slender, abruptly dilated into a wide cylindrical glabrous throat with slender erect teeth: akenes narrowly linear, $5^{\mathrm{mm}}$ long, equaling the fine white hardly scabrous pappus.

This is seemingly a well marked species, occurring in the moist woods of the northern Rocky mountains. I have seen four collections of it as follows: Henderson, Cascade mountains, Oregon, July I 8, I 896 , distributed as A. Latifolia; Sandberg and Leiberg, Stevens pass, Washington, distributed as $A$. Chamissonis, A'1gust 1893 ; R. S. Williams (no. 443), Columbia falls, June I8, 1894; Belt mountains, Montana, July 24, I899. Of the latter two I cannot be very certain, as they are not now at hand. This species seems nearest to the recently described $A$. ventorum Greene (based upon one of my numbers), a species of which I now have several collections.

Arnica stricta, n. sp.-Very erect with gradually tapering stem, $2-3^{\mathrm{dm}}$ high, tomentose pubescent throughout: leaves about 5 pairs, the lower pairs exceeding the internodes, gradually smaller upward, the upper half of the stem nearly naked; the lowest pair lanceolate, acute, $3-5^{\mathrm{cm}}$ long, tapering into a slender petiole usually shorter than the blade; the next I or 2 pairs similar but with shorter petioles; the upper and smaller pairs sessile by 
a broad base: inflorescence of about 5 heads subtended by a pair of ovate-lanceolate bracts, $\mathrm{I}-2^{\mathrm{cm}} \mathrm{long}$, in a close rounded corymb, the terminal head and the first pair very short peduncled: terminal head much the largest, IO- $12^{\mathrm{mm}}$ high and about as broad: involucral bracts in 2 series, shorter than the disk, narrowly oblong, obtusish, the tip tinged with purple and tomentoseciliate: rays few, short, broad, slightly narrowed at apex: tube of disk corollas pubescent, the glabrous throat scarcely dilated: akenes very minutely pubescent; pappus dirty-white, minutely scabrous.

The specimens on which this species is based were collected in 1892 by Mr. J. D. Parker, somewhere in southern Wyoming. Specimens were sent to the Gray Herbarium for determination. The name returned was $A$. folios near var. incana Gray. Now that Dr. Greene has helped us to a more definite knowledge of $A$. incana (Pitt. 4: I69), this may with safety be designated by a name.

Arnica celsa, n. sp. - Perennial from horizontal rootstocks and fleshy roots, erect, tall, $4-6^{\mathrm{dm}}$ : the strict stems lightly striate, sparsely pubescent with flat spreading hairs, upwardly becoming also obscurely glandular-viscid: leaves (exclusive of the foliar bracts) 6-8 pairs, puberulent and sprinkled with microscopic shining resin particles, narrowly oblong or oblanceolate, tapering to both ends, many of them 3 -nerved; the lower small, $2-3^{\mathrm{cm}}$ long, equaled by the slender petioles which abruptly dilate into the equally long ocreae; ocreae and leaves gradually shorter upward; middle stem leaves longest $\left(8-\mathrm{IO}^{\mathrm{cm}}\right)$, sessile or with short petioles and ocreae; the uppermost sessile and partly clasping: lower internodes short, much exceeded by the leaves, gradually longer upwards and above much exceeding the leaves: heads $3-5$, on rather slender leafy-bracted peduncles; involucre and peduncles moderately glandular-viscid; the bracts approximately uniserial, oblong, much shorter than the $12-15^{\mathrm{mm}}$ high disk: rays $\mathrm{I} 2-20$, about 7 -nerved, 2 or 3 -toothed, $10-14{ }^{\mathrm{mm}}$ long: tube of disk corollas slender and pubescent below, gradually dilated into an equally long glabrous sub-cylindric upper portion with short spreading glabrous teeth: akenes sub-glabrous, 
nearly linear, tapering downward, the scabrous pappus equaling the corolla tube.

This excellent species was found growing in abundance on the wet, meadow-like banks of a mountain streamlet at an altitude of 8000 feet. The nearest ally known to me is $A$. ocreata Aven Nelson, from which it differs in its pubescence and wholly different disposition of its leaves. The habit of the inflorescence, too, is very unlike, which in the species now proposed consists of subequal heads always corymbosely disposed.

No. 7643 , Tie city, Albany county, July 20, I 900 , is the type.

Arnica rhizomata, n. sp.-Conspicuously rhizomatous, the creeping rootstocks slender, sheathing-bracteate at the nodes, giving rise at intervals to the erect leafy stems and a few fleshy roots: pubescence whitish, soft, almost arachnoid, minutely granular-glutinous underneath the pubescence on the inflorescence: stems $2-5^{\mathrm{dm}}$ high : leaves $5-7$ pairs, rather uniformly distributed, oblong-lanceolate, from obtuse to acute; the lowest pair with short scarious-margined petioles, early deciduous; the next I or 2 pairs $6-9^{\mathrm{cm}}$ long, about $2^{\mathrm{cm}}$ broad, on short margined petioles which dilate at base to form the short ocreae; the upper pairs sessile, shorter: heads $3-5$, IO- $12^{\mathrm{mm}}$ high, or sometimes more numerous and then smaller: peduncles mostly short, erect, the lateral often exceeding the terminal: involucre campanulate, the bracts much shorter than the disk, narrowly oblong, obtusish : corolla long-pubescent on the tube, sometimes a few straggling hairs on the lobes: akenes linear, almost glabrous, the pubescence short and scattering, half as long as the $8^{\mathrm{mm}}$ corolla: pappus fulvous or dirty-white.

This species has been collected several times and has been held as a form of $A$. foliosa, or rather as variety incana. Such a disposition is no longer tenable, neither am I able to refer it to the species $(A$. foliosa Nutt.). It seems rather to belong to a section of which $A$.ocreata, $A$. celsa, and this are the principal members. In so far as this region is concerned, the following collections represent it: 8012 , Lincoln gulch, Albany county, August 8, I900 (type); 1417, B. C. Buffum, Pine creek, 1892; Green mountain, July 6, $1896 ; 3587$, North Vermillion creek, July 17,1897 .

\section{UNIVERSITY OF WYOMING, Laramie, Wyo.}




\section{$2 \mathrm{BHL}$ Biodiversity Heritage Library}

Nelson, Aven. 1901. "Contributions from the Rocky Mountain Herbarium. II." Botanical gazette 31(6), 394-409. https://doi.org/10.1086/328121.

View This Item Online: https://www.biodiversitylibrary.org/item/90521

DOI: https://doi.org/10.1086/328121

Permalink: https://www.biodiversitylibrary.org/partpdf/223092

\section{Holding Institution}

Missouri Botanical Garden, Peter H. Raven Library

\section{Sponsored by}

Missouri Botanical Garden

\section{Copyright \& Reuse}

Copyright Status: Public domain. The BHL considers that this work is no longer under copyright protection.

This document was created from content at the Biodiversity Heritage Library, the world's largest open access digital library for biodiversity literature and archives. Visit BHL at https://www.biodiversitylibrary.org. 